Bangladesh J. Zool. 42(2): 277-282, 2014

\title{
RECORD OF HUMERANA HUMERALIS (BOULENGER 1887) FROM RANGPUR DISTRICT OF NORTH-WESTERN BANGLADESH
}

\author{
H. Al-Razi, M. A. Baki* and S. M. I. Alam \\ Department of Zoology, Jagannath University, Dhaka-1100, Bangladesh
}

\begin{abstract}
A male Bhamo frog Humerana humeralis was first time collected from Rangpur, Bangladesh, outside its usually habitat. The dorsal surface was characteristically olive brown to bright green in colour and the ventral surface was whitish. Black spots were distributed between nostril and between eyes. The length of snout-vent, head, snout were found to be $43.25 \mathrm{~mm}, 14.50 \mathrm{~mm}$ and 7.5 $\mathrm{mm}$, respectively. Some information of its natural history is also included in the paper.
\end{abstract}

Key words: Humerana humeralis, Distribution, Northwestern Bangladesh

\section{INTRODUCTION}

Humerana humeralis Boulenger, 1887 is known to be a rare anuran species (Family: Ranidae) in Bangladesh (Chakma 2009). Although the species is globally considered as Least Concern, the population of this species is however decreasing (Paul van Dijk et al. 2004). The species is known to occur in Myanmar (Boulenger 1887, 1890), Nepal (Schleich and Kästle 2002), Nagaland (Ao et al. 2003), Assam and Arunachal Pradesh (Hussain et al. 2007) of India. Description of collected samples of $H$. humeralis seems to be very necessary since there is no reliable published morphometric data for this species in Bangladesh. Khan (2008), Chakma (2009), Feeroz et al. (2011) and Feeroz (2013) recorded this species from Teknaf, Khagrachari and Rema-Kalenga wildlife sanctuary. Recently, Hasan et al. (2014), however, reported this species from Panchagarh district of Bangladesh.

Because of its dynamic geological history and partitioned insular geographical features (Hamilton 1979, Hall 1996), Southeast Asia is one of the most diverse and yet poorly understood amphibian fauna on the planet (Chowdury 1996). Only a very few studies have been published providing a check list of Bangladesh amphibians (Asmat 2007, Chowdury 1996, IUCN Bangladesh 2000; Kabir et al. 2009, Khan 1982, 2004, 2008 and Sarker and Sarker 1988). Several articles (Paul van Dijk et al. 2004, Asmat 2007, Chakma 2009, Feeroz et al. 2011 and Khan 2008) mentioned the presence of H.humeralis in eastern Bangladesh. Unfortunately, no morphological description (including measurements such as snout-vent length SVL) has been provided by them,

\footnotetext{
*Author for correspondence: <mabaki@gmail.com>.
} 
although size can be a good indicator for classification and scientific validation of a species in frogs (Matsui et al. 2007).

\section{MATERIAL AND METHODS}

Surveys on amphibians were undertaken during evening and night. Observations of the live specimens of this species were made in Rangpur city $\left(25^{\circ} 44^{\prime} 19.76 " \mathrm{~N} 89^{\circ} 15^{\prime} 13.50 " \mathrm{E}\right)$ during October 2013. Three individuals were observed and only a male specimen was collected on October 14, 2013 at 2100 hours. The specimen was captured using a small net and was preserved in $10 \%$ formalin. Specific identity was confirmed based on morpho-meristic data of the live specimen using the key and expanded description provided by Hussain et al. (2007). The species and the measurements were verified by Dr. Kaushik Deuti, Amphibia Section, Zoological Survey of India, $27 \mathrm{JL}$ Nehru Road, Kolkata 700016, India. Measurements were recorded using a digital slide caliper with an accuracy of $0.2 \mathrm{~mm}$.

Morphometry: Measurements were taken in $\mathrm{mm}$. Morphometric characteristics included the following measurements: 1.Snout-vent length (SLV). 2. Head length (HL). 3. Head width (HW). 4. Snout length (SL). 5. Tympanum diameter (TYD). 6. Eye diameter (ED). 7. Distance between Nostrils (DN). 8. Relation of fingers length (RFL). 9. Relations of toe length (RTL) have taken on the basis of Hussain et al. (2007).

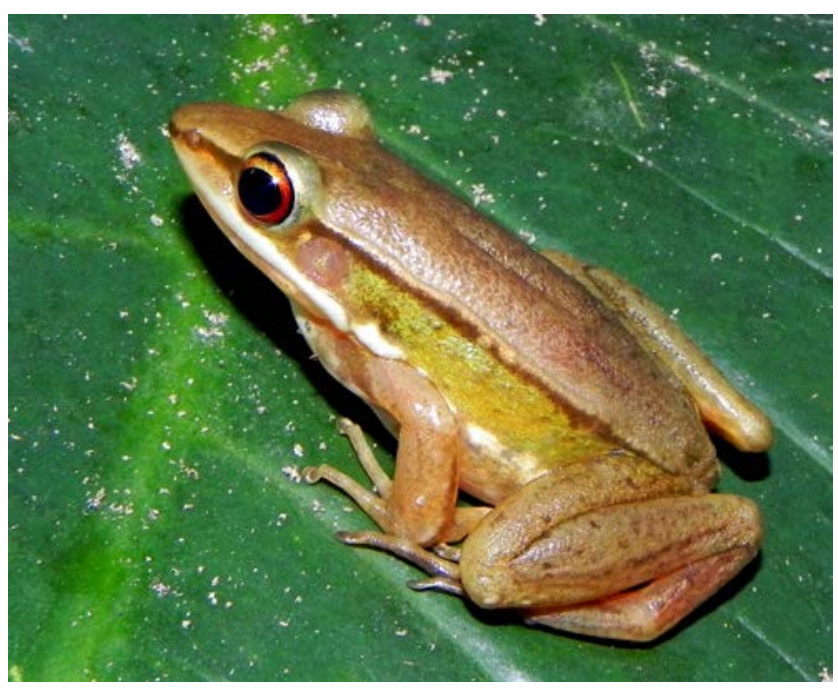

Plate 1. Dorsolateral view of Humerana humeralis male from Rangpur, Bangladesh 


\section{RESULTS AND DISCUSSION}

Morphological characteristics: The collected specimen was a medium sized male (Plate 1). Dorsal side is olive brown to bright green in colour while whitish in ventral parts. Black spots are distributed between nostrils and in between eyes. Skin is smooth dorsally; posterior part of the back is slightly granular. Lateral part of the body is greenish and the ventral side is smooth and whitish. Uniformly tuberculated dorsum has two golden brown folds from the eye to groin. White line continues from each side of flanks to upper jaw. Upper jaw bounded by a lining of white to bright yellow, which extended up to rectal gland. Humeral gland present on the base of the forelimb. Forelimbs are with small black spots and the base is light greenish. Hind limbs with black spots distributed on femur, tibia and tarsus; dorsolateral folds are bright yellow. Hind limbs have no cross bars.

Head is large, which is nearly equal in length and breadth. Snout obtusely pointed and projected beyond the mouth. Snout is obtusely pointed and projecting beyond the mouth. The nostril is closer to the tip of the snout than eye. The tympanum is rounding, distinct and is nearly $3 / 4$ of the eye. The supratympanic fold starts from the anterior corner of the eye and ends with an elongated gland at the base of the back of mandible, which lies horizontally. Another elongated gland lies horizontally just above the base of the forelimb and separated by a very small distance from earlier. The humeral gland is present at the base of the forelimb. 1st finger is slightly longer than the 2nd finger. The relative length of the fingers is $\mathrm{F} 2<\mathrm{F} 1<\mathrm{F} 4<\mathrm{F} 3$. Fingers are provided with distinct dermal border. The tips of the finger are dilated into discs which are longer than broad and triangular (Plate 2). Black spots are distributed on femur, tibia and tarsus. The relative length of the toes is $\mathrm{T} 1<\mathrm{T} 2<\mathrm{T} 3<\mathrm{T} 5<\mathrm{T} 4$. Outer metatarsal tubercle is absent. Tibia is long; foot length is greater than tibia length. The measurements of different body parts are given in Table 1.

Table 1. Measurements $(\mathrm{mm})$ of different morphological characteristics of $\boldsymbol{H}$. humeralis (male) collected from Rangpur city.

\begin{tabular}{lc}
\hline Character & $\begin{array}{c}\text { Measurement } \\
(\mathrm{mm})\end{array}$ \\
\hline Snout-vent length (SVL) & 43.25 \\
Head length (HL) & 14.50 \\
Head width (HW) & 13.35 \\
Snout length (SL) & 7.5 \\
Tympanum diameter (TYD) & 3.80 \\
Eye diameter (ED) & 4.85 \\
Distance between Nostrils (DN) & 4.65 \\
Relation of fingers length (RFL) & $\mathrm{F} 2<\mathrm{F} 1<\mathrm{F} 4<\mathrm{F} 3$ \\
Relations of toe length (RTL) & $\mathrm{T} 1<\mathrm{T} 2<\mathrm{T} 3<\mathrm{T} 5<\mathrm{T} 4$ \\
\hline
\end{tabular}




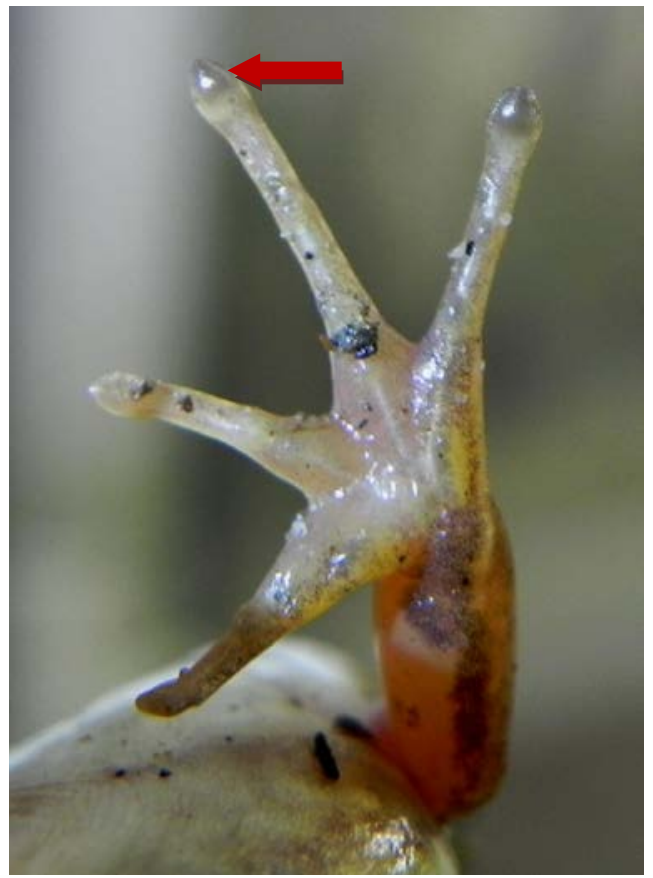

Plate 2. Forelimb of $H$. humeralis male.

Natural history: The frog was found at night on an Kochiri pana (Eichhornia sp.) plant in a small ditch one foot above the surface. Temperature was around $25^{\circ} \mathrm{C}$ and the weather was rainy. The plant was floating in an almost dry small water body, surrounded by Colocasia esculenta, Cynodon dactylon and Enhydra fluetuans vegetations. Habitat was very close to the locality, near a boundary wall of a house. It was only 50 meters away from the Dhaka-Rangpur highway. The distance from capture site to the known small river was near $10 \mathrm{~km}$.

This is the most abundant species in flood-prone areas (Hussain et al., 2007), although Rangpur city is neither a flood-prone area nor any large river or forest is present in this area. There is no published article with detailed morphometric discussion of this species from Bangladesh so far. Chakma (2009), however, echoed the discussion of Hussain et al. (2007) and in recent times, Hasan et al. (2014) have provided a short description with its distribution notes and morphometric feature including SVL and forelimb finger ratio. In this sense, it is the first record of this species from Bangladesh with detailed morphological data based on a collected specimen.

Acknowledgements: The authors are thankful to Dr. Kaushik Deuti, Amphibia Section, Zoological Survey of India, 27 JL Nehru Road, Kolkata 700016, India for verifying the species, Mahbubul Haque Ruhso, Rafiul Kabir and Mobassher 
Alam for their help during field work, to Professor Ghazi S. M. Asmat, Department of Zoology, University of Chittagong for providing related papers and Department of Zoology, Jagannath University, Dhaka for instrumental support.

\section{LITERATURE CITED}

AO, J. M., BORDOLOI, S. and OHLER, A. 2003. Amphibian fauna of Nagaland with Nineteen new records from the state including five new records for India, Zoos' Print J., 18(6), 1117 - 1125.

ASMAT, G. S. M. 2007. Update list of the amphibians of Bangladesh, Bannaprani-Bangladesh Wildlife Bull., 4 (1-2): 3.

BOULENGER G. A. 1887. An account of batrachians obtained in Burma by M. L. Fea, of the Genova Civic Museum, Ann. Mus. Genoa, 2(5): 418 - 424.

BOULENGER G. A. 1890.The Fauna of British India, Including Ceylon and Burma. Reptilia and Batrachia, Taylor and Francis, London.

CHAKMA, S. 2009. Humerana humerali in:Kabir, S.M.H., Ahmed, M., Ahmed, A.T.A., Rahman, A.K.A., Ahmed, Z.U., Begum, Z.N.T., Hassan, M.A., and Khondker, M. (eds.). 2009. Encyclopedia of Flora and Fauna of Bangladesh, Vol. 25. Amphibians and Reptiles. Asiatic Society of Bangladesh, Dhaka, pp. 31-32.

CHOWDHURY, M.M. 1996. Ecology of Amphibians of Bangladesh, M. Sc. Thesis (unpublished), Jhangirnagar University, Dhaka, Bangladesh.

FEEROZ, M.M., HASAN, M.K., and KHAN, M.M.H. 2011. Biodiversity of protected areas of Bangladesh, Vol. I. Rema-Kalenga Wildlife Sanctuary. Biotrack. Arannayk Foundation. Dhaka, Bangladesh, pp. 101-102.

FEEROZ, M.M (ed.). 2013. Biodiversity of protected areas of Bangladesh, Vol. $\boldsymbol{W}$ : Teknaf Wildlife Sanctuary. Biotrack. Arannayk Foundation. Dhaka, Bangladesh, pp. 119-120.

HALL, R. 1996. Reconstructing Cenozoic SE Asia, in: R. Hall and D. J. Blundel (eds.), Tectonic Evolution of Southeast Asia, Bath, UK, Geological Society Publishing House. pp.153-83

HAMILTON, W. 1979. Tectonics of the Indonesianregion. United States Geological Survey Professional Papers. 1078: 1 -345.

HASAN, M. K., KHAN, M. M. H. and M. M. FEEROZ. 2014. Amphibians and Reptiles of Bangladesh: A Field Guide. Arranyak Foundation. $191 \mathrm{pp}$.

HUSSAIN, B., J. GOGOI, N. K. CHOUDHURY, B. K. BARUAH, D. K. SHARMA, J. KALITA, and SENGUPTA, S. 2007.'Rana humeralis - A new record from Assam and Arunachal Pradesh, India, with notes on its morphometry and natural history.Russian Journal of Herpetology, 14(3): 2007, pp. $167-171$.

IUCN BANGLADESH, 2000. Red Book of Threatened Amphibians and Reptiles of Bangladesh. IUCNThe World Conservation Union, Dhaka, Bangladesh, XII+95 pp.

KABIR, S.M.H., AHMED, M., AHMED, A.T.A., RAHMAN, A.K.A., AHMED, Z.U., BEGUM, Z.N.T., HASSAN, M.A., and KHONDKER M. (eds.). 2009. Encyclopedia of Flora and Fauna of Bangladesh, Vol. 25. Amphibians and Reptiles. Asiatic Society of Bangladesh, Dhaka. 204 pp.

KHAN, M. A. R.1982. Wildlife of Bangladesh: A checklist. University of Dhaka, Dhaka Bangladesh. $174 \mathrm{pp}$.

KHAN M. A. R. 2004. Checklist of Herpetofauna of Bangladesh. Cobra. 75: 1-29.

KHAN M. M. H. 2008. Protected Areas of Bangladesh - A Guide to Wildlife. Nishorgo Program, Bangladesh Forest Department, Dhaka, Bangladesh. 256 pp.

MATTSUI, M., TODA, M. and OTA, H.2007.A new species of frog allied to Fejervarya Limnocharis from the southern Ryukyus, Japan (Amphibia: Anura). Current Herpetology.26:65-79. 
PAUl VAN DIJK, P., WOGAN, G., DUTTA, S., OHLER, A., SHRESTHA, T.K. and ASMAT, G.S.M. 2004. IUCN Red List of Threatened Species. Version 2013.1, URL: http://www.iucnredlist.org (last accessed on October 28, 2013).

SARKER, M. S. U. and SARKER, N. J. 1988. Wildlife of Bangladesh. A Systematic List with Status, Distribution and Habitat. The Rico Printers, Dhaka.59 pp.

(Manuscript received on 1 September, 2014; revised on 4 November, 2014) 